\title{
Middle East. A Few Remarks on Geography, History and Art
}

\begin{abstract}
This article results basically from personal impressions gathered during my visits to the Middle East in 1994, 1998, 2002, 2011 and 2017, as well as from some suggested readings. Special emphasis is laid on geographical factors, as well as on historical circumstances connected with architecture and sculpture in the ancient Middle East. Important to stress is that the tale of the Mesopotamian hero Gilgamesh is much more than the first epic ever written in the world; Gilgamesh's wish for immortality is the drama of every single man, no matter if he lived in ancient Mesopotamia during the $3^{\text {rd }}$ millennium BC, or if he lives in the $21^{\text {th }}$ century's Manhattan.
\end{abstract}

Keywords: old empires, culture, Greek miracle, Mesopotamia, Egypt
Volume 2 Issue 3 - 2018

\section{João Vicente Ganzarolli de Oliveira}

Professor and Researcher of the Tércio Pacitti Institute of the Federal University of Rio de Janeiro, Brazil

Correspondence: João Vicente Ganzarolli de Oliveira, Professor and Researcher of the Tércio Pacitti Institute of the Federal University of Rio de Janeiro, Brazil, Rio de Janeiro (RJ, 2 I 94I-90I,Tel +552 I-3938-9600, Email jganzarolli@usa.com

Received: May 26, 2018 | Published: June 29, 2018

\section{Introduction}

Surrounded by seas and deserts, larger than the Holy Roman Empire at its height but smaller than China, the Middle East is neither a continent nor a country. As a geographical entity, it is the region where the three continents that formed the so-called Old World meet. Such a characterisation is still too vague. Apart from the countries located in the intersection between Europe, Asia and Africa-that is to say, Turkey, Syria, Lebanon, Israel and Egypt-, the Middle East also comprises Iraq, Iran and all the countries of the Arabian Peninsula. Arguably, Ethiopia, Libya, Sudan, South Sudan and Afghanistan could also be included, given their cultural affinities (Figure 1).

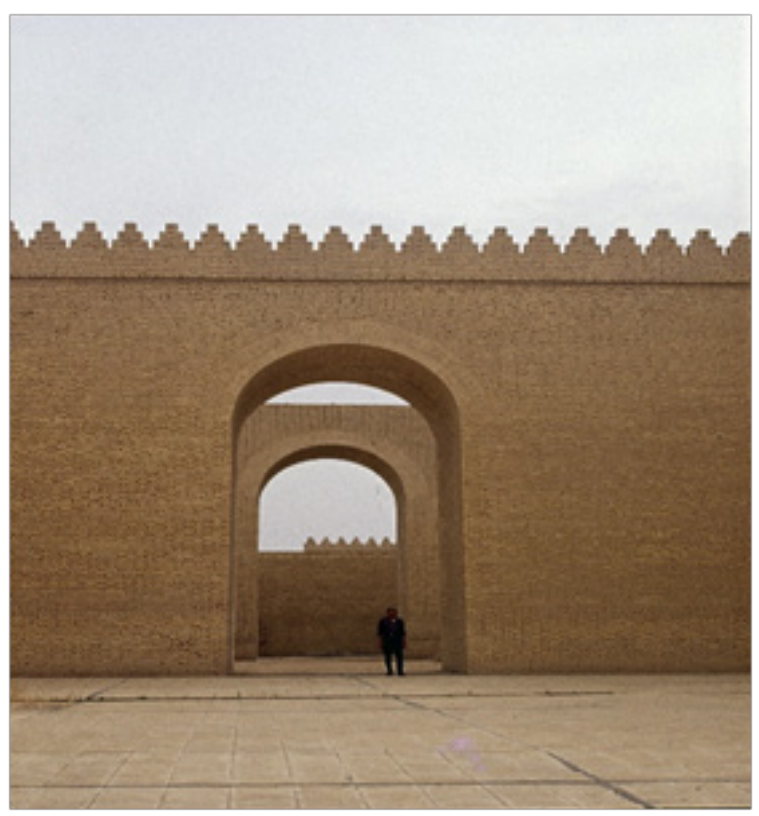

Figure I Restored walls of Babylon (Southern Mesopotamia): photo taken by the author.

\section{Cradle of Civilization}

Middle East is the cradle of the civilization. Between the fifth and the fourth millennia $\mathrm{BC}$, high advanced cultures started to develop and to thrive in Mesopotamia and Egypt. The presence of big and generous rivers in terms or fertilization of the soil-namely the Tigris, the Euphrates and the Nile respectively-in this crescent-shaped region (hence "Fertile Crescent") propitiated the invention of agriculture and irrigation. The Middle East is the birthplace of written language. Through millennia, great cultures and empires (Sumer, Babylon, Assyria, Egypt, Hittite, Persia, Seleucia...) flourished and perished within its limits. The Persian Empire represents the first attempt of cultural unification for the Middle East. Its borders practically coincided with those of the Empire of Alexander the Great, conqueror of the Persians-and whose death, in $323 \mathrm{BC}$, marked the beginning of the Hellenistic Age, which would last until 31 BC, when Caesar Augustus' authority as Emperor was established. From Iberia until the banks of the Euphrates River, Rome (daughter of the Hellenism Alexander had founded) reigned supreme. Far from being an obstacleas the Atlantic Ocean had been until 1492, the year Columbus discovered America-, the Mediterranean Sea promoted the contact between the peoples who lived around it, due to the relative proximity between its edges. Both geographically and culturally, the peninsula of Anatolia acted as something like a bridge between Asia and Europe; no wonder that Turkey has more ancient cities in its territory than any other place in the world. Travelling westwards, scientific ideas came from Mesopotamia, crossed Anatolia, reached Ionia and the Greek Balkans-a phenomenon that is linked to the cultural rise of Greece in the second half of the 1st millennium $\mathrm{BC}$, and that we usually call the Greek miracle. ${ }^{1}$ Travelling eastwards, Alexander and his armies of soldiers, scientists, philosophers and artists crossed Anatolia, swept down through Mesopotamia and continued until the Indus valley, sowing Greek culture wherever they passed: "In 334 BC Alexander crossed the Hellespont from Europe to Asia, and the world was never the same again. (...) It was incredible, breath-taking.

At one point he and his army covered four hundred miles in ten days". ${ }^{2}$ When Herodotus, repeating his predecessor Hecataeus,

${ }^{1}$ See, for instance, Jean-Pierre Vernant. Origens do pensamento grego (translated by Manuela Torres), Lisboa, Teorema, 1982, p. 138 et passim.

${ }^{2}$ John Ferguson. The Heritage of Hellenism. The Greek World from 323 to 31 $B C$, London, Thames and Hudson, 1973. p. 7. In ancient times, Anatolia was also a centre of diffusion of some innovations, such as the use of chariots in the war by the Hittites, considered by some authors as "the most important 
defined Egypt as a gift of the Nile, ${ }^{3}$ he provided more than the best definition ever provided of the land of the Pharaohs. In doing so, he gave us an example of how deeply the physical geographic of a country can influence the possibilities of human life within it. The dry climate, with an extreme shortage of rains, contributed to emphasise the role of the Nile River, with its regular floods, as the responsible for the very existence itself. In the words of William Stevenson Smith, "The regular rise of the Nile every year provided the striking example of a renewal of life with each annual flood and gave the Egyptian a cheerful assurance of the permanence of established things, suggesting the acceptance that life would somehow continue after death in the same way". ${ }^{4}$ For Mesopotamia, the "land between rivers", as the Greek denominated it (cf. mésos=middle and potamós=river), a paraphrase of Herodotus' sentence is $100 \%$ valid: Mesopotamia is a gift of the Euphrates and the Tigris. From a very remote past, those twin rivers have left a deposit of sedimentary rocks, linking this way the Arabian plateau to the Zagros Mountains. Regarding the happy combination between extension and fertility, we do not find anything comparable along the 3.700 kilometres of almost completely arid lands that separate the Nile and the Indus. In climatic terms, we can say that the Middle East is squeezed between the hottest areas of the world: the Sahara and Northwest India.

What would be the destiny of humanity if Cleopatra's nose were shorter? This is just one of the many unanswerable historical questions that we inherited from the Old World. Indeed, "The historianphilosopher will never stop meditating about the nose of Cleopatra. If this nose had seduced the gods as it did seduce Cesar and Anthony, an Alexandrian Gnosticism diffused could have been imposed in the place of the Christian doctrine dictated by the two Romes: the ancient, the one of the Tiber, and the new, that of the Bosphorus. (...) Let us recognise the facts" ${ }^{\prime \prime}$. The very concepts of History and Geography comes from there-more specifically from the works of Hecataeus of Miletus and Herodotus of Halicarnasus, both authors being born in Asia Minor (Miletus and Halicarnasus, formerly Greek cities, respectively). A meaningful fact is that, with the exception of the statue of the god Zeus, sculpted by Fidias in European Greece, all the Seven Wonders of the World are concentrated in the Middle East. Unfortunately, nothing but ruins remains of the Hanging Gardens of Babylon and most of those seven colossal works of architecture and sculpture. Only the Pyramid of Cheops-the oldest of them-was well succeeded in coping with the misfortunes brought by Nature and culture. In Babylon and Assyria, clay prevailed as raw material for

invention of the second millennium BC" (C. W. Ceram. O segrêdo dos Hititas (translated by Milton Amado), Belo Horizonte, Itatiaia, 1959, p.279; see also I. Temisoy et al. The Anatolian Civilisations Museum, Ankara, Donmez, 1997. p. 37.

${ }^{3}$ The Histories, II, 5.

${ }^{4}$ The Art and Architecture of Ancient Egypt (revised with additions by William Kelly Simpson), $3^{\text {rd }}$ edition, London, Yale University Press, 1981, p. 15 According to the same author, "The peculiarly Egyptian concern with life after death in a form similar to that which had been experienced upon earth provided an element in the development of the arts which was not present to such an extent in other countries. Thus, while architecture, painting, and sculpture ordinarily appeared in the service of the cult of a god to glorify the wealth and power of a ruler, in Egypt we find emphasis laid upon providing a lasting dwelling-place for the dead, the re-creation of life magically in pictures to serve him, and lastly the provision of a substitute in stone for his perishable body" (Ibid).

${ }^{5}$ See Georges Roux. La Mésopotamie, Paris, Éd. du Seuil, 1995, p. 22 et passim. ${ }^{6}$ Arnaldo Momigliano. Sagesses barbares (translated by Marie-Claude Roussel), Paris, Gallimard, 1979. p. 11. building; in Egypt, stone has always been abundant. This contingence helps to explain the destruction of the majority of the old monuments of Mesopotamia, as well as the survival of so many of their Egyptian counterparts. In Egypt, the practice of cutting stones into big blocks was rapidly established. Both the architect and the sculptor were supplied with an enormous amount of regularly geometric blocks, hence the Egyptian tendency towards pyramidal, cubical and prismatic forms in architecture and sculpture, as well as the prominence of works of large scale in those arts. In contrast with this favourable situation, the ancient Mesopotamians had to import stone. Their land supplied them only with small and round stones-no wonder the rounded forms and the substantial fragility of Sumerian sculptures; differing from their neighbours in Egypt, ancient Mesopotamian sculptors had a predisposition towards spherical and conical shapes. The same can be said of architecture: Egypt is the land of the pyramids; Mesopotamia is the land of the ziggurats.

\section{Conclusion}

There is ample evidence to indicate that the rise of civilization in the ancient Middle East would be inconceivable without the favourable conditions offered by the Tigris, the Euphrates and the Nile. Mutatis mutandis, the same relation is valid for India and the Indus River, China and the Yangtze River, the Inca Empire and the Titicaca Lake. Here we find an important point to be considered: on the one hand, water supplied by rivers and lakes are a geographical condition for the advent of a civilized society; on the other hand, such a condition is not enough. When in excess, water can be an obstacle for civilized life. With $6.992 \mathrm{~km}$ length, the Amazon River is the longest in the world, and the Amazonia basin has been inhabited since several millennia. Nonetheless, most of the Amazonian native peoples had not surpassed a Neolithic standard of living until the arrival of the Europeans, in the 16th century; even nowadays many of them live as though they were still in prehistoric times. Sufficient evidence exists to suggest that the humid Amazon rain forest, with its typical impenetrability, is a discouragement for large scale agriculture, architecture, engineering, high population density, centralized political structures, intense social stratification, large scale trading and all other elements that characterize a civilized society. ${ }^{7}$ What is clear is that modern technology and patterns of life in general tend to become more and more planetary-a matter that ignites debates that are beyond the boundaries of this article. Not to be forgotten is that the tale of the Mesopotamian hero Gilgamesh is much more than the first epic ever written in the world; Gilgamesh's wish for immortality is the drama of every single man, no matter if he lived in ancient Mesopotamia during the 3rd millennium $\mathrm{BC}$, or if he lives in the 21 th century's Manhattan. In closing, I echo the words of a French geographer whose work was kindly offered to me during my stay in Ethiopia, in January 2011: "Geography was invented because the curious-minded man wanted to understand how things were arranged on the Earth's surface. (...) His thirst for knowledge was stronger than his fear of knowing nothing. Piercing through the darkness they acted as geographers". ${ }^{8}$

${ }^{7}$ See Edward Lanning. Peru before the Incas, Englewood Cliffs, PrenticeHall, 1967, p. 3; Victor von Hagen. Der Ruf der Neuen Welt. Deutsche bauen Amerika, Ilm, Knaur, 1974, p. 113 et passim; and Hannah Flint. "Who are the Amazon's uncontacted tribes?”, in The Telegraph, 31 Jul 2014.

${ }^{8}$ Sylvain Tesson. Petit traité sur l'immensité du monde, Paris, Ed. Équateurs, 2005, p. 77; see also Kay Anderson et al. Handbook of Cultural Geography org. Kay Anderson et al, Londres/Thousand Oaks/Nova Déli, SAGE, 2003, pp. XVIII-XIX. 


\section{Acknowledgements}

None.

\section{Conflict of interest}

The auhtor declares there is no conflict of interest. 